\title{
Hometown Politics and the American Protective Association, $1887-1890$
}

\author{
JO ANN MANFRA
}

The American Protective Association (or "A.P.A.") was Founded by your humble Servant, March 13th 1887-at Clinton, Iowa, In Room "6" Toll Block-one Sunday afternoon.

- H. F. Bowers ${ }^{1}$

AT THE INVITATION of attorney Henry Francis Bowers, a small group of Clintonians met in Bowers's downtown law office to organize the American Protective Association (APA). Within the next several years, with Bowers as "supreme president," the APA spread to both coasts. Perhaps a half-million strong in its own right by the early 1890s, this highly secretive order also coordinated a wide array of "patriotic" societies that militantly opposed the perceived political influence of the Roman Catholic church in the United States. In the nation's Gilded Age, concludes the distinguished historian John Higham, the APA was the single expression of organized anti-Catholicism that "ultimately developed real power."

The national organization's meteoric rise and precipitous decline have been documented in detail, and various mono-

1. H. F. Bowers to O. S. Wright, 16 March 1894 (photocopy), Henry F. Bowers Collection, State Historical Society of lowa, Des Moines.

2. Ibid.; Donald L. Kinzer, An Episode in Anti-Catholicism: The American Protective Association (Seattle, 1964), 35, 123-24, 177-80, 190; John Higham, Strangers in the Land: Patterns of American Nativism, 1860-1925, rev. ed. (New York, 1971), 62 (quotation), 63, 80-87.

THE ANNALS OF IOWA 55 (Spring 1996). CThe State Historical Society of Iowa, 1996. 
graphs on the late nineteenth century include limited references to the APA. ${ }^{3}$ Unlike the extensive scholarly literature on the anti-Catholic and similarly secretive Know Nothing movement of the 1850s, however, few works study the APA at the state and local levels. ${ }^{4}$ There is no study of the organization's activities in Iowa as a whole, and the APA's life in Clinton remains obscured by an extremely sparse documentary record. Neither Henry Bowers's personal papers in the State Historical Society of Iowa nor the Clinton newspapers of the late 1880s and early 1890 s directly mention the society's local activities or its membership. ${ }^{5}$ Interviews conducted by a half-dozen scholars with

3. The only overview of the APA as a national organization is Kinzer, Episode
in Anti-Catholicism, which supersedes Humphrey J. Desmond, The A.P.A.
Movement (Washington, DC, 1912; reprint, New York, 1969). The most recent
discussion appears in David H. Bennett, Party of Fear: From Nativist Movements
to the New Right in American History (Chapel Hill, NC, 1988), 171-79. For a
synthesis of the relationship of anti-Catholicism to partisan politics in the
Gilded Age, see Paul Kleppner, The Third Electoral System, 1853-1892: Parties,
Voters, and Political Cultures (Chapel Hill, NC, 1979), 215-22, 228-37.

4. No monograph on the APA has appeared since Kinzer's Episode in AntiCatholicism. As for articles, only one has been cited in the politics subdivision of the Journal of American History's ongoing bibliographical listings since the introduction of that category in June 1981: Jo Ann Manfra and Robert Kolesar, "Irishmen, Elites, and Reformers: Behavioral Continuities in Nineteenth Century Anti-Catholicism," Mid-America 76 (1994), 27-52, which contains a comparative analysis of the APA's relationship to political change in Clinton and Worcester, Massachusetts. An older article, whose title suggests an overview of APA activities in Wisconsin, addresses only the "labor policy" advocated by Milwaukee's Wisconsin Patriot, which billed itself as the unofficial newspaper of the APA in the Badger State. K. Gerald Marsden, "Patriotic Societies and American Labor: The American Protective Association in Wisconsin," Wisconsin Magazine of History 41 (1958), 287-94. Respecting the Know Nothing movement, see especially William E. Gienapp, "Nativism and the Creation of a Republican Majority in the North before the Civil War," Journal of American History 72 (1985), 529-59; John R. Mulkern, The. Know-Nothing Party in Massachusetts: The Rise and Fall of a People's Movement (Boston, 1990), 115-73; and Tyler Anbinder, Nativism and Slavery: The Northern Know Nothings and the Politics of the 1850s (New York, 1992).

5. Two comprehensive bibliographies on Iowa history contain no references to the APA. See William J. Petersen, comp., Iowa History Reference Guide (Iowa City, 1952); and Patricia Dawson and David Hudson, comps., lowa History and Culture: A Bibliography of Materials Published Between 1952 and 1986 (Ames, 1989). The various published indexes to the Iowa Historical Record and the Annals of Iowa do not refer to the APA. The Iowa Journal of History and Politics 
old Clintonians, in person or by mail, are valuable in identifying the order's founders and offering occasional snippets of "inside" information, but reveal nothing about the APA's rank and file and little about the organization's local career. By reconstructing that career and situating it in Clinton's late nineteenthcentury political landscape, this study of the first APA chapter in the United States questions the generally accepted dismissal of the APA as just another entry in the annals of American bigotry, one more example of the way in which nativism appealed to those frustrated by complex socioeconomic pressures in a multiethnic society. ${ }^{6}$

THE APA grew out of Clinton's turbulent political history. The town was founded in 1855, and within twenty-five years it had become one of the most important lumber processing centers on the upper Mississippi River. Until the late 1870s, its officeholders tended to be Republicans drawn from the ranks

index cites a single article mentioning the existence of an APA chapter in Shelby County, which disbanded after "a short time" because of "internal dissension." John J. Louis, "Shelby County: A Sociological Study," lowa Jourrial of History and Politics 2 (1904), 233. Clinton County histories tend to mention the APA only in connection with Bowers's role as founder. The first county history, compiled in 1879 before the advent of the order, includes a biography of Bowers. The county's 1901 Biographical Record notes that Bowers's "labors in connection with the American Protective Association have gained him national fame," and that "he is the founder of that organization." Patrick B. Wolfe repeats these remarks, adding only that a local church edifice "at one time ... was used by the A.P.A.'s, a peculiar anti-Catholic society." A 1946 survey mentions neither Bowers nor his organization. The latest county history includes a good capsule biography of Bowers together with a forthright denunciation of the APA, but offers no details on its local career. The History of Clinton County, Iowa (Chicago, 1879), 671; The Biographical Record of Clinton County, Iowa (Chicago, 1901), 21-23; Patrick B. Wolfe, ed., Wolfe's History of Clinton County, Iowa, 2 vols. (Indianapolis, 1911), 1:162, 552-53; Estelle Goodwin LePrevost Youle, History of Clinton County, Iowa (n.p., 1946); History of Clinton County, Iowa (Clinton, 1976), 113, 423.

6. Higham and Bennett argue that the fears and anger of economically displaced and status-anxious Americans in an age of change and uncertainty lay at the core of the reemergence of anti-Catholicism in the 1880s and 1890s, a contention Kinzer does not challenge. All three concur that the APA, as Kinzer puts it, "differs little from hundreds of other such groups that have been organized in the country." Higham, Strangers in the Land, 53, 85-87, 97-98; Bennett, Party of Fear, 174-76, 179; Kinzer, Episode in Anti-Catholicism, 249. 
of "old-stock" business and professional men. The Democrats then began an almost decade-long domination of local politics. The new political authority, however, posed no challenge to Clinton's economic elite. This elite, a small and powerful group of families, controlled the lumber industry, the banks, and the major municipal franchises.

As was true elsewhere, the emergence of an immigrant community had much to do with energizing Clinton's Democratic Party. By 1880 voters of foreign birth or parentage outnumbered old-stock voters. Germans made up 15 percent of Clinton's total voting population, men of British birth or background 13 percent, Scandinavians (mainly Danes and Swedes) 8 percent, and other foreign-born voters 6 percent. ${ }^{8}$ Irish Catholics, however, were most evident; by the early 1880 s, first- and second-generation Irishmen made up 22 percent of the city's political population. Clinton's foreign-born and old-stock voters distributed themselves unevenly across the city's four wards (see table). A German minority (26 percent) set the tone in Ward 1. Old-stock voters easily commanded Ward 2. British, Irish, and old-stock voters shared Ward 3. Irishmen held a strong plurality (38 percent) in Ward 4. Local folk thought of Wards 1 and 4 as the "immigrant wards," but all, with the exception of Ward 2, were heavily blue-collar in occupational composition. ${ }^{9}$

By the mid-1880s the almost solidly Democratic Irish played a pivotal role in Clinton politics. Although they fought for their own political advantage within the Democratic Party, they did not contest the developmental urban vision articulated by the town's largely Republican business leaders. Indeed, the Clinton

7. Manfra and Kolesar, "Irishmen, Elites, and Reformers," 30 . For the lumber industry in Clinton, see George Wesley Sieber, "Sawmilling on the Mississippi: The W. J. Young Lumber Company, 1858-1900" (Ph.D. diss., University of Iowa, 1960). Clinton's late nineteenth-century politics can be followed in the town's three extant newspapers from the period. The Age and the News were Democratic papers, the Herald was Republican.

8. For a good retrospective on Clinton's nineteenth-century German, Danish, and Swedish neighborhoods, see Youle, History of Clinton County, 83-84, 86-87, 90-91.

9. Manfra and Kolesar, "Irishmen, Elites, and Reformers," 30-31. Voters' religious affiliations appear in Census of Iowa, 1895, Manuscript Population Schedule, Clinton County, Clinton Township, City of Clinton, Wards 1-5. 
TABLE

FIRST- AND SECOND-GENERATION VOTER NATTVITIES BY WARD, 1880

\begin{tabular}{lcccc}
\hline & $\begin{array}{c}\text { Ward 1 } \\
\mathrm{N}=723 \\
\%\end{array}$ & $\begin{array}{c}\text { Ward 2 } \\
\mathrm{N}=522 \\
\%\end{array}$ & $\begin{array}{c}\text { Ward 3 } \\
\mathrm{N}=333 \\
\%\end{array}$ & $\begin{array}{c}\text { Ward 4 } \\
\mathrm{N}=763 \\
\%\end{array}$ \\
\hline U.S. ("old-stock") & 36 & 52 & 32 & 27 \\
Ireland & 15 & 11 & 25 & 38 \\
Germany & 26 & 18 & 5 & 9 \\
Scandinavia & 9 & 3 & 7 & 11 \\
Great Britain & 9 & 12 & 22 & 8 \\
Other foreign & 5 & 5 & 9 & 6 \\
& 100 & 101 & 100 & 99 \\
\hline
\end{tabular}

SOURCE: Tenth Census of the United States, 1880, Manuscript Population Schedule, Clinton County, IA, districts 289-90.

Irish were indispensable members of a political alliance between the Democratic Party and the Republican elite that allowed the business community to maintain its traditional power over the formation and implementation of municipal policy. ${ }^{10}$

Then, in 1885, the nation's largest labor organization, the Noble and Holy Order of the Knights of Labor, came to town. In Clinton as elsewhere, working-class Irish immediately assumed a prominent role in the organization; District Deputy Master Workman Martin Hassett, for example, was an Irishborn railroad machinist who was active in Ward 4 politics. Soon other millworkers from the city's immigrant wards filled its four local ("mixed-occupation") assemblies, sharing with the Irish a desire to win from their prosperous employers so-called bread-and-butter concessions, especially higher wages. ${ }^{11}$

10. For the accord between Cinton's Democratic Party and its Republican establishment, see Manfra and Kolesar, "Irishmen, Elites, and Reformers," especially 31-33, 44-49.

11. Ibid., 34-35; Leon Fink, Workingmen's Democracy: The Knights of Labor and American Politics (Urbana, 1983), xiii-xiv, 52, 99, 225; Steven P. Erie, Rainbow's End: Irish-Americans and the Dilemmas of Urban Machine Politics, 1840-1895 (Berkeley, 1988), 8, 30, 49, 50, 253; Jonathan Garlock, comp., Guide to the Local Assemblies of the Knights of Labor (Westport, CT, 1982), 115. Martin Hassett, a forty-three-year-old native of County Clare, had lived in Clinton since the late 1860s. Portrait and Biographical Album of Clinton County, Iowa (Chicago, 1886), 590. For Hassett's activism in Ward 4 politics, see Clinton Weqkly Age, 2, 9 March, 7 September 1883, 25, 29 February 1884. There is no full-length work on Iowa's Knights, but see Ralph Scharnau, "The Knights of Labor in Iowa," 
The Knights of Labor, however, was not a conventional union. By 1886 its social-reform ideology had everywhere thrust it directly into politics, and Clinton's Knights enthusiastically followed suit. With Irish, German, and Scandinavian workingclass voters as its base, a Knights of Labor political ticket, led by attorney Arnold Winkelried Walliker, entered the 1886 city election. ${ }^{12}$

During the campaign Arnold's closest advisers were his elder brother and law partner, Jacob Henry Walliker, and attorney Henry Bowers, who occupied an office next door to the Wallikers. Both the elder Walliker, a Democrat, and Bowers, a Republican, had long been active in Clinton politics. By 1883, when Bowers was a city alderman and Jacob Walliker was city clerk, they had become fast friends. They shared a common reform outlook despite their party differences. Both refused to allow public policy to serve the private interests of the business community. Acting on his reformist beliefs, Jacob had entered Clinton's 1885 mayoral contest as an independent, claiming that 'his' candidacy represented "a blow at ring rule and bossism." He was defeated. ${ }^{13}$

Arnold Walliker, as it happened, was a relative newcomer to Clinton politics. He had practiced law in western Iowa until 1883 , when he moved to Clinton to form a partnership with his elder sibling. Arnold shared the reform outlook of his brother and Bowers. Following Jacob's defeat in 1885, Arnold emerged

Annals of lowa 50 (1991), 861-91. For a discussion of the relevance of class to American politics and culture, see Richard Oestreicher, "Urban Working-Class Political Behavior and Theories of American Electoral Politics, 1870-1940," Journal of American History 74 (1988), 1257-86.

12. Manfra and Kolesar, "Irishmen, Elites, and Reformers," 35; Fink, Workingmen's Democracy, 26.

13. Levern C. Chance and Velma Walliker Chance, Walliker-Laufenbeck Genealogy (Davenport, 1978), 20,70-71; Manfra and Kolesar, "Irishmen, Elites, and Reformers," 33-34; Clinton Weekly Age, 6 March 1885 (quotation). For the location of the two law offices, see the City Directory for 1885-86 [for] Clinton and Lyons (Clinton, 1885), 46, 148. Bowers's active role on the city council in crafting public policy led to his serious consideration as the Republican mayoral nominee in 1884, but the GOP decided to endorse the Democratic candidate. Clinton Weekly Age, 15 February 1884; Clinton Daily Herald, 28 February 1884; Manfra and Kolesar, "Irishmen, Elites, and Reformers," 31-32. 
as the leader of the reform triumvirate. Arnold "deems himself an agitator," remarked an editor who heard him speak, "with a mission to stir up the laboring classes, ... preparing the way for the revolution which he says must come sooner or later." His 1886 election bid, on the Knights of Labor ticket, triumphed. ${ }^{14}$

Inaugurated in March 1886, Mayor Walliker promptly challenged the influence that business leaders, acting through the Democratic Party, exercised over local affairs. He did so by embracing an agenda that accords well with historian Leon Fink's enumerated "uses of political power" pursued by Knights of Labor regimes throughout the country. The Walliker administration diversified and extended municipal services in areas - transportation, communication, utilities - in which public authority most obviously colluded with private "monopoly." The administration also increased taxes on the city's water and gas companies and on its two largest lumber companies. In addition, the city council ended various practices that businessmen believed were conducive to recruiting capital investment and middle-class migrants. ${ }^{15}$

By early 1887 , however, the Knights' political effectiveness was doomed. The city's political and business leaders, now convinced that the Knights' challenge was less a protest than an effort to build a permanent class-based party, set about enticing the Irish back to the Democratic fold. In that spirit, the press of both parties attacked Arnold Walliker rather than the Knights, caricaturing the mayor as a "modern agitator - selfish, unprincipled and ignorant." Walliker was "the greatest enemy the

14. Chance and Chance, Genealogy, 21-22, 73-74; Manfra and Kolesar, "Irishmen, Elites, and Reformers," 34-36; Clinton Weekly Age, 5 March 1886; Clinton Morning News, 28 October 1886 (quotation). On Arnold's reform rhetoric, see also Clinton Morning News, 10 October 1886; and Clinton Weekly Herald, 14 October 1886. A Knights ticket also won in the adjacent town of Lyons. Lyons Weekly Mirror, 6 March 1886. Prior to Clinton's 1894 annexation of Lyons, the communities were separate civic entities. Wolfe, History of Clinton County, 1:388. Neither Clinton nor Lyons is listed in Fink's enumeration of towns and cities where labor tickets appeared between 1885 and 1888. Fink, Workingmen's Democracy, 28-29.

15. Fink, Workingmen's Democracy, 30-32, 34, 57. Walliker's reform program is fully explored in Manfra and Kolesar, "Irishmen, Elites, and Reformers," 35-39. 
working man could possibly have," one editor insisted. The "interests of all classes - laborer and capitalist alike-demand that the reins of the Clinton municipal government be rescued from [his] incompetent and dangerous hands. ${ }^{16}$

The anti-Walliker campaign, in turn, exposed an increasingly deep ethnic split within the local Knights assemblies. Mayor Walliker and his brother Jacob were of Swiss and Bavarian background. Henry Bowers also was of German ethnicity, his immigrant father having anglicized the name Bauer. Arnold's most important link to Clinton's blue-collar rank and file was laborer Simon Woldenberg, the top official of the Germania Assembly. Led by Woldenberg, the German members of the Knights and their Scandinavian allies - moved, it appears, by some mixture of ideological conviction and simple ethnic fellowship - signaled their firm support of the reform mayor's administration. ${ }^{17}$

Meanwhile, the city's traditional leadership initiated a bipartisan Citizens' ticket for $1887 .{ }^{18}$ According to a local newspaper, "prominent Knights of Labor" joined Democrats and Republicans in nominating a coalition slate headed by John W. Pollock, an Irish-American businessman. Shortly thereafter the Irish Knights, a majority within Clinton's assemblies, officially repudiated Walliker by refusing to help field a separate labor ticket. In response, the Germania Assembly renominated Walliker as an independent candidate. Labeling Walliker's slate the

16. Clinton Morning News, 1 (third quotation), 9 (second quotation) February, 6 March (first quotation) 1887; Clinton Weekly Herald, 10 February 1887; Clinton Weekly Age, 11 February 1887; Manfra and Kolesar, "Irishmen, Elites, and Reformers," 39-40.

17. For the Walliker brothers, see Tenth Census of the United States, 1880, Manuscript Population Schedule, Clinton County, IA, district 290, dwelling 774; Census of Iowa, 1885, Manuscript Population Schedule, Clinton County, Clinton Township, City of Clinton, pp. 230, 368; and Chance and Chance, Genealogy, 8-10. For Bowers, see Tenth Census of the United States, 1880, Clinton County, district 289, dwelling 752; Census of Iowa, 1885, City of Clinton, p. 227; and Kinzer, Episode in Anti-Catholicism, 39. Woldenberg would later own a small business and become president of the town's German Association. Directory for 1885-86, 153; Clinton and Lyons City Directory for 1893 (Clinton, 1893), 34, 410.

18. The generic Citizens' Party, according to Leon Fink, Workingmen's Democracy, 96, was a widespread contemporary phenomenon and "a most effective counterweight to independent labor politics." 
"sausage ticket," the Citizens' coalition promised to redeem Clinton from its disastrous fling with structural reform. ${ }^{19}$

At this strategic moment, as former members of the American Protective Association in Clinton later recalled, Rev. E. J. McLaughlin, pastor of St. Mary's Catholic Church, intervened directly. In a pre-election sermon, Father McLaughlin asked his predominately Irish parishioners (among them Martin Hassett, the top officer of the Knights of Labor) to vote against Arnold Walliker's reelection. ${ }^{20}$

McLaughlin, like most other Catholic clerics, may have been suspicious of the Knights of Labor as a secret organization. In any case, he was not alone in appealing to Clinton's Irish workingmen as Catholics. Those opposed to the Knights' involvement in local politics had long since played the religious card by publicizing a controversy within the American Catholic church over whether or not the Knights should be formally censured. ${ }^{21}$ Clinton's Republican and Democratic papers assiduously reported the ongoing debate, especially when leading churchmen and various Catholic organs warned the laity against being led astray by militant socialists and anarchists intent on politicizing the Knights. ${ }^{22}$

19. Clinton Morning News, 27 February 1887 (second quotation); Clinton Weekly Herald, 10 March 1887 (first quotation); Manfra and Kolesar, "Irishmen, Elites, and Reformers," 40-41. There is no indication that the Knights of Labor split in Clinton became a subject of the organization's official correspondence. Kinzer, Episode in Anti-Catholicism, 271n.

20. A. P. Stauffer, "Anti-Catholicism in American Politics, 1865-1900" (Ph.D. diss., Harvard University, 1933), part 2, 70n, 71. Stauffer identifies McLaughlin by name in Alvin P. Stauffer Jr. to Francis Kelley, 13 January 1934, Diocese of Davenport Archives, St. Vincent Center, Davenport. Established in 1865 or 1866, St. Mary's was the oldest Catholic parish in Clinton. Wolfe, History of Clinton County, 1:160-61; History of Clinton County (1879), 515-16, 685. Hassett was a charter member of St. Mary's. Portrait and Biographical Album, 590.

21. This issue was not resolved until 1888. For a summary of the debate and its resolution, see Jay P. Dolan, The American Catholic Experience: A History from Colonial Times to the Present (Garden City, NJ, 1985), 330-33.

22. Shortly after the $1886 \mathrm{Knights}$ of Labor political victory, the Herald had published an article subtitled "No Good Roman Catholic Can Be A Knight of Labor." Clinton Weekly Herald, 6 May 1886. See also Clinton Morning News, 14 August, 3 October, 11, 31 November, 3, 10, 11 December 1886, 4, 8, 12, 15 , 16, 20, 25 January, 6 March 1887; and Clinton Weekly Age, 7, 14 January 1887. 
Whether or not "ecclesiastical influence" turned out to be decisive in the anti-Walliker campaign, as former members of the APA later insisted, on election day the reform mayor went down to defeat. His support in Irish Ward 4 dropped 24 percentage points from where it had stood in 1886. Clinton's business elite rejoiced. According to the Republican newspaper's headlines, citizens had "Joined Forces and Redeemed Clinton From Threatened Blight of Socialism," proclaiming that "THERE is NO PLACE IN CLINTON FOR ANARCHISM." ${ }^{23}$

The devastating election occurred on Monday, March 7, 1887. The following Sunday afternoon Arnold Walliker, Jacob Walliker, Henry Bowers, and several other men met to form the American Protective Association. ${ }^{24}$

WHO WERE THESE OTHER MEN? Unfortunately, the sources disagree. Although revealing no names, Bowers claimed that seven men organized the APA. An elderly Arnold Walliker told Ruth Knox Stough that the founders of the APA included Simon Woldenberg, William Andrews, Louis Emmons, Phillip Mudgett, and a man with the surname Wilson. Historian Fritiof Ander confirmed the identities of Andrews and Mugget (as he spelled it) and added two others to the list-Charles Huzzy and Charles Flanigan. Edmund Burke, a longtime Clinton lawyer, informed Mary Callista Hynes that the original group included Woldenberg, Socrates Bates, L. W. Miller, and Dr. R. S. Rathburn. Because the various informants totally agreed only as to Bowers and the Wallikers, historian Donald Kinzer sought clarification in 1952 from Bowers's daughter-in-law, but without success. ${ }^{25}$

23. Stauffer, "Anti-Catholicism," part 2, 71 (first quotation); Clinton Weekly Herald, 10 March 1887 (second quotation); Manfra and Kolesar, "Irishmen, Elites, and Reformers," 42.

24. Bowers to Wright, 16 March 1894; Kinzer, Episode in Anti-Catholicism, 36. 25. Albert C. Stevens, comp., The Cyclopedia of Fraternities, $2 \mathrm{~d}$ ed., rev. (New York, 1907), 295; Ruth Knox Stough, "The American Protective Association" (M.A. thesis, University of Nebraska, 1931), 1; Fritiof Ander, "The SwedishAmerican Press and the American Protective Association," Church History 6 (1937), 165; Mary Callista Hynes, "The History of the American Protective 
Woldenberg, Andrews, and Mudgett each appear in two of the listings. Woldenberg, as already mentioned, was one of Mayor Walliker's most vigorous supporters in the 1887 campaign. Andrews is most likely William G. Andrews, a "fresco artist" in partnership with his father in a Clinton house- and sign-painting business. Mudgett is no doubt Phillip P. Mudgett, who in 1887 was still residing in the nearby village of Camanche. Two years later he moved to Clinton to become a supervisor at the W. J. Young \& Company lumber mill, and later worked as a foreman for the Chicago \& North Western Railroad there. ${ }^{26}$

At least some information can be uncovered on all of the remaining presumed founders except Flanigan and Wilson. Socrates C. Bates was a Clinton cabinetmaker. Dr. Robert S. Rathbun (rather than Rathburn) was a Clinton dentist. The eldest son of a deeply pious Methodist clergyman, the Ohio-born Rathbun characterized himself as "strongly Republican." The man identified as Louis Emmons is most likely L. E. Emmons, a Clinton laborer. Charles Huzzy is evidently C. W. Hussey, secretary of the Iowa Drain, Tile, Brick \& Lime Company in Clinton. L. W. Miller is probably Ludwig Miller, a Germanborn Clinton shoemaker. ${ }^{27}$

Association in Minnesota" (M.A. thesis, Catholic University of America, [1931?]), 1; Kinzer, Episode in Anti-Catholicism, 271n. The identified founders' names appear here as given by Stough, Ander, and Hynes, rather than as reproduced by Kinzer, who in several instances departs from the spelling in the original sources. Kinzer, Episode in Anti-Catholicism, 272.

26. For Woldenberg, see note 17 above. For Andrews, see Directory for 1885-86, 9, 38; and Directory for 1893, 54. For Mudgett, see Directory for 1885-86, 259; Clinton Morning News, 23 July 1889; Directory for 1893, 284; and Wolfe, History of Clinton County, 1:121-24, 378-79.

27. For Bates, see Directory for 1893, 64. For Rathbun, Emmons, Hussey, and Miller, see Directory for 1885-86, 16, 67, 87, 111, 127. For Rathbun, see also Portrait and Biographical Album, 655-56. Although the published 1885 census compilation contains summary data for the entire city of Clinton, the population data for Ward 1-Walliker's stronghold - is missing from the 1885 manuscript census, which may in part explain why Miller is the only one of the several other APA founders who could be located in that enumeration. Frank D. Johnson, comp., Census of Iowa for the Year 1885 (Des Moines, 1885), 101; Census of Iowa, 1885, City of Clinton, p. 381. In the directory, Miller's first name is "Ludwig," but in the census, he is listed as "Lewis." In both sources, however, Miller's address is the same: 729 Camanche Avenue. 
Collectively, these charter members neither belonged to the community's economic elite nor conform to the historical characterization of APA members as inarticulate common folk. Rather, they resembled the "middle-class" artisan and small entrepreneurial Republican reformers of Worcester, Massachusetts, whose opposition to the long-standing alliance of their party's elite with Irish Democrats evidently provoked a large number of them to become anti-Catholic activists. ${ }^{28}$

As this interpretation suggests, the APA's principal organizers in Clinton-Bowers and the Walliker brothers-should not be dismissed as simply anti-Catholic bigots. Bowers, in fact, maintained friendships with a number of local Catholics. He was raised a Protestant (with a Lutheran father and a New England-born Methodist mother), but often claimed that his only personal brush with religious discrimination occurred in his native Maryland in the $1850 \mathrm{~s}$, when Catholic pressure on the state legislature had forced the closing of all public schools. Although he blamed this decision for denying him a formal education and later cited the episode as a personal motivation for establishing the APA, there is no record that any such thing actually happened in antebellum Maryland. As for the Wallikers, their father also was Lutheran. Their mother, a Catholic, had been deprived of schooling in her native Bavaria and could neither read nor write until middle age - a circumstance that Jacob attributed to the general attitude "at that time in Catholic countries." In her later years, he added, his mother "renounced the Catholic religion," becoming a Baptist. ${ }^{29}$

Although none of the other identified founders had a history of overt anti-Catholicism, William Andrews would later become president of the local chapter of the Patriotic Order of the Sons of America, one of the nativist organizations that cooperated with the APA for political purposes. Bates and Rathbun, along with Bowers and Jacob Walliker, were active in local

28. Richard Jensen, The Winning of the Midwest: Social and Political Conflict, 1888-1896 (Chicago, 1971), 232; Manfra and Kolesar, "Irishmen,' Elites, and Reformers," 45-46, 49-51.

29. Kinzer, Episode in Anti-Catholicism, 38-40; Hynes, "History of the APA in Minnesota," 3; Chance and Chance, Genealogy, 9, 10 (quotations). 
Masonic lodges. According to John Higham, the Masons, "being tinged by an anti-Catholic heritage, provided a source of membership for the A.P.A., and often a body of political allies." Yet Masonic officers often served as public spokesmen for local Knights of Labor assemblies, evidently having no problem associating with a heavily Catholic labor organization headed at the national level by a second-generation Irishman. ${ }^{30}$

Indeed, a number of the charter members of the APA were also members or firm supporters of the Knights of Labor. Both Wallikers took advantage of a special dispensation to join; ordinarily they would had been excluded from the ranks because the Knights banned lawyers (as well as bankers, speculators, gamblers, liquor dealers, and professional "office seekers") from membership. Simon Woldenberg served as an officer in the Germania Assembly. Henry Bowers, while perhaps not an official member, publicly supported the organization's reform agenda. Although local Knights' membership lists have not survived, the demographic characteristics of the other presumed founders of the APA suggest that most of them could have joined Clinton's labor assemblies. One historian flatly claims that all belonged to the Knights of Labor. ${ }^{31}$

Anti-Catholicism was, however, an effective rallying cry and made political sense to the men who gathered in Bowers's office that Sunday afternoon in 1887. Arnold Walliker later noted that the charter members had formed APA Council No. 1 because they were alarmed by Catholic influence in the Knights organi-

30. Directory for 1885-86, 26; Directory for 1893, 24, 54; Kinzer, Episode in AntiCatholicism, 34, 40-41, 59, 79-81, 123-24, 177-80, 190; Chance and Chance, Genealogy, 71; Wolfe, History of Clinton County, 1:188-89; Higham, Strangers in the Land, 80; Fink, Workingmen's Democracy, 55; Henry J. Browne, The Catholic Church and the Knights of Labor (Washington, DC, 1949), 39, 190. Bowers himself argued that the United States of America "was founded" by the Masons, and that the APA was an offspring of Masonry. H. F. Bowers to Henry Baldwin, 11 August 1898, Henry Baldwin Letters, Library Americana, Manuscript Division, New York Public Library, New York.

31. Stough, "American Protective Association," 2; Fink, Workingmen's Democracy, 64; Stauffer, "Anti-Catholicism," part 2, 71. For examples of Bowers's promotion of the Knights of Labor political activity in the city and county of Clinton, see Clinton Weekly Herald, 26 August 1886, and Clinton Morning News, 6, 8 March 1887. 
zation and in Clinton generally. ${ }^{32}$ The APA founders reasoned that local Irish Catholics, encouraged by their parish priest, had been responsible for the defeat of Mayor Walliker and his political agenda; Irishmen had abandoned reform and returned to the Democratic Party and its alliance with the business community. Unable to neutralize the economic elite itself, ex-mayor Walliker and his labor supporters struck out instead at the elite's Irish allies. They appealed to latent anti-Catholic sentiment not from some paranoid abandonment of fundamental policy concerns, but rather as a political continuation of their fight against entrepreneurial hegemony in Clinton.

"WE BEGAN OUR WORK first at home, the 'City of Clinton, Iowa,'" Bowers later recalled. But the APA's local "work" has remained veiled in mystery. Although Clinton newspapers routinely published membership lists of various fraternal orders, including the ostentatiously secret Masons, they never mentioned the existence of APA Council No. 1. Perhaps neither Republican nor Democratic editors wished to risk offending Irish voters, the pivotal group in the newly revitalized political alliance that had triumphed in 1887. Editors may have also neglected to mention the APA because of their positions as town boosters. Nineteenthcentury small-urban journalists normally served not only as purveyors of news to the local population but also as publicity agents for their growing communities. So far as possible, editors routinely ignored news about social conflicts deemed damaging to a thriving entrepreneurial image. Thus, while Clinton's 1887 triumph over "anarchism" merited blaring headlines, accounts of the subsequent activities of the APA never saw print. ${ }^{33}$

32. Stough, "American Protective Association," 2-3.

33. Bowers, quoted in M. E. Eckelberg, "The American Protective Association Connection and the Reverend Frederic Cyrille Jean," Social Justice Review 74 (1983), 90. For the city's secret fraternal organizations, see, for example, Clinton Weekly Age, 14, 28 January, 8 April, 6 May 1887. The widespread editorial penchant for boosterism generally appears to have been a holdover from the "booster journalism" of the nineteenth-century frontier. See the brief discussion of newspaper public relations strategies in Robert R. Dykstra, The Cattle Towns (New York, 1968), 382-83. Regarding a special promotional issue of the Clinton Weekly Age, filled with typical public relations matter about local entrepreneurial opportunity, see Manfra and Kolesar, "Irishmen, Elites, and Reformers," 36. 
Editors also had to reckon with the order's own rigid secrecy. "As has often been told," Bowers later recollected of himself and his Clinton associates, "we were without honor in our own land. Some [were] afraid of their political chances. Some their business. Some even their lives." Such fears, whether or not grounded in reality, may help explain why Bowers imposed such tight security within the APA that the name of no national officer other than his own for the years $1887-1893$ has ever come to light. ${ }^{34}$ Also contributing to the order's secrecy, as later became clear in other locales, was its preference for propagandizing and recruiting through the many overt patriotic societies that proliferated in the 1880 s and 1890 s. Clinton's patriotic orders - the Loyal Orange Institution, the Patriotic Order of the Sons of America, and the Junior Order of United American Mechanics - were nationally organized associations that everywhere maintained confidential ties to the APA. According to historian Donald Kinzer, the APA "was at one and the same time a secret society with its own distinct membership list, and a federation for political purposes of self-styled 'patriotic societies.'" But Clinton's editors were no more forthcoming about the activities of these APA front groups than they were about the APA itself. ${ }^{35}$

Although the APA was cloaked in secrecy, its founders pursued a public mission. At first they concerned themselves solely with Clinton politics. APA charter members, like their middle-class counterparts in Worcester, Massachusetts, correctly perceived the Irish as defenders of the elite's policy-setting prerogatives. Thus the initial business on Council No. 1's agenda,

34. Bowers, quoted in Eckelberg, "American Protective Association," 90; Kinzer, Episode in Anti-Catholicism, 55. In 1894 the man who succeeded Bowers as APA supreme president used virtually the same words to describe the need for organizational secrecy all across the land. It was, he said, "entirely due to the fact that members of the 'A.P.A.', when suspected or known to be such, have been so mercilessly boycotted as to drive them out of business, and not unfrequently out of the towns and cities in which they lived." W. J. H. Traynor, "The Aims and Methods of the 'A.P.A.,"' North American Review 159 (1894), 74.

35. Higham, Strangers in the Land, 57-58; Directory for 1893, 32. For the relationship between the APA and patriotic orders, see Kinzer, Episode in AntiCatholicism, 34, 55, 59-62, 68-73, 79-81, 92, 100-102, 106, 109, 114-15, 123-24, 132,177 (quotation), 178-80, 187, 190, 213, 215. For the interdependence of patriotic societies and the APA in Worcester, see Manfra and Kolesar, "Irishmen, Elites, and Reformers," 49-51. 
as it would be for APA chapters in communities all across the land, was the elimination of Irish electoral influence. In Clinton, as in Worcester, the plan to exclude the Irish was not an end in itself but rather a means to reform. In Worcester the goal was to cleanse and reorganize the public school system; in Clinton the aim was, less narrowly, to rejuvenate Arnold Walliker's workingmen's democracy in city government. ${ }^{36}$

German-Irish ethnic antagonism within Clinton's Democratic Party played directly into the APA's hands by energizing a fertile source of anti-Irish bias. ${ }^{37}$ In 1886, according to later allegations, the German Knights had opposed the labor ticket candidacy of Joseph O'Donnell for county clerk solely on ethnic grounds. The Irish, explained an irate editor, "know that Joe was cut and slashed in the ranks of the K. of L. on account of his nationality, and they are prepared to resent it with force and effect." A few months later, the Irish Knights refused to cooperate with their German counterparts in fielding a second labor ticket headed by Arnold Walliker. Instead, Irish leaders within the Knights actually participated in selecting the triumphant anti-Walliker Citizens' slate. $^{38}$

By late summer 1887, it became clear that the Irish would pay a high price for their betrayal of reform politics. Irishman D. O'C. McCarthy, the incumbent county auditor, failed to win renomination at the Clinton County Democratic convention. Additionally, both German-language newspapers in the county

36. Stauffer, "Anti-Catholicism," part 2, 72; Manfra and Kolesar, "Irishmen, Elites, and Reformers," 45-49. Scholars concur that the APA focused its attention on Irish Catholics in local politics. See, for example, Bennett, Party of Fear, 173-74; Geoffrey Blodgett, The Gentle Reformers: Massachusetts Democrats in the Cleveland Era (Cambridge, 1966), 149-53; Higham, Strangers in the Land, 86-87; Jensen, Winning of the Midwest, 237; Kleppner, Third Electoral System, 216, 219, 235, 365; and Samuel T. McSeveney, The Politics of Depression: Political Behavior in the Northeast, 1893-96 (New York, 1972), 13, 102, 138.

37. Everywhere in the nation, says Paul Kleppner, "where German Lutherans perceived Democracy as the 'Catholic party,' they reacted negatively." In some places, according to Richard Jensen, even German Catholics, who had always clashed with their Irish coreligionists, "seemed to enjoy the fact that the [APA] concentrated its venom on its rivals, the Irish Catholics." Kleppner, Third Electoral System, 216, 219, 365; Jensen, Winning of the Midwest, 76, 236.

38. Clinton Morning News, 13 February 1887. 
came out against the convention's nominee for Seventh District judge, Irishman M. V. Gannon of Davenport. ${ }^{39}$

Most of the city's Germans were Lutheran, and like their coreligionists elsewhere in the Middle West, they had weaker ties to either major party than most immigrant groups. In Iowa a strong majority had voted Democratic after the state's GOP sponsored a liquor prohibition initiative in $1882 .{ }^{40}$ Four years later, Clinton's Germans formed the most loyal constituents of the Knights of Labor ticket that swept Walliker into office. In 1887 the Irish, by returning to the Democratic Party, destroyed the Knights' political leverage, and by then only a small faction within the city's GOP advocated local enforcement of the prohibition law. ${ }^{41}$ The Germans were, therefore, vulnerable to being nudged by the APA toward the welcoming embrace of the Republican Party. ${ }^{42}$

In November, just before the 1887 county election, Henry Bowers announced that he and ex-mayor Walliker would offer political remarks to a gathering at Clinton's German Hall. A local editor predicted that "many old-time admirers will endeavor to hear Mr. Bowers speak," while "Mr. Walliker's labor friends

39. Clinton Weekly Herald, 1 September 1887; Clinton Weekly Age, 2, 9 September, 28 October 1887.

40. Clinton Weekly Age, 10,17 November 1882; Kleppner, Third Electoral System, 153-58, 306-28. For religious data, see Census of Iowa, 1895, City of Clinton.

41. In 1884 the Iowa legislature wrote prohibition into statute law, forcing Clinton's Democratic administration to stop licensing the city's saloons. The elected officials agreed, however, to a quiet compromise: the town's saloons would not be closed down, but a body of previously neglected regulatory ordinances was to be strictly enforced. Clinton's predominantly Republican economic elite found itself more comfortable with this arrangement than with the agenda of its party's Reform Club faction, made up of devout prohibitionists. Despite the so-called Saloon War in the spring of 1886, in which mobs terrorized and injured men attempting to enforce the prohibitory law, the compromise remained intact. Clinton Weekly Age, 14, 21, 28 February, 7 March, 18, 25 July, 1 August 1879, 5 March 1880, 4, 11 March, 24 June, 19 August 1881, 13, 20 April 1883, 7 March, 18 April, 20, 27 June, 15 August 1884, 1, 8 April 1887; Clinton Morning News, 15 January 1885, 29 March 1887; Clinton Weekly Herald, 22 April, 6 May, 10, 24 June 1886.

42. As Donald Kinzer puts it, "with local variations, the A.P.A. operated within the Republican party. ... That Irish Catholics usually, voted for Democrats . . . was the most prominent piece of evidence explaining the A.P.A. affinity for the Republican party." Kinzer, Episode in Anti-Catholicism, 140-41. 
alone will fill the house." At the appointed hour Simon Woldenberg introduced his two APA colleagues to an overflow crowd "mostly [composed of] German and Scandinavian workingmen" who greeted the pair with "loud and long cheers." ${ }^{\text {"43 }}$

It was apparently their first joint public appearance since the overthrow of Walliker's labor administration the previous March. Bowers and Walliker each spoke at some length on "local politics." ${ }^{\prime 4}$ Although the newspaper failed to disclose the burden of their remarks, the ethnic composition of the workingclass audience strongly suggests that, at the least, the two reiterated their well-known reform agenda. Given the timing of the meeting - on the eve of the county election - it seems a safe guess that Bowers and Walliker joined the editors of the Germanlanguage newspapers in opposing Irishman M. V. Gannon's election.

On election day Gannon was among those few Democrats who failed to win Clinton County; in the city, he carried only one voting unit-Irish Ward 4. A Democratic editor held a Republican conspiracy responsible both for Gannon's loss and for D. O'C. McCarthy's failure to win renomination. The conspirators, he charged, "succeeded in dividing our forces by pitting one ... nationality against another. ... We do not know who did the dirty work, but there was more of it done, and in a more indecent and disgusting manner than we thought possible even by the Republican party. ${ }^{\prime 45}$

The same indignant editor charged the unnamed troublemakers of the 1887 county election with using identical tactics in the 1888 city election. As APA alumni later recalled, Council No. 1 played an active role in that municipal contest. Mayor Pollock, having faithfully served the interests of Clinton's business elite for a term, thought he deserved a second year in office. The Republicans, however, decided to field their own municipal

43. Clinton Daily Herald, 5, 7 November 1887.

44. Clinton Daily Herald, 7 November 1887. For Bowers and Walliker's earlier campaign rallies, see Manfra and Kolesar, "Irishmen, Elites, and Reformers," $38,42$.

45. Clinton Weekly Herald, 10 November 1887; Clinton Weekly Age, 11 (quotation), 18 November 1887. 
slate. Democrats loyally renominated Pollock, despite what the delighted Republican editor described as "a good-sized speck of revolt in the ranks of the city Democracy." Specifically, Clinton's German-language newspaper expressed displeasure with the Democratic ticket. The political signal seemed clear: the Germans were in the process of deserting the Democratic Party. ${ }^{46}$

The resulting GOP victory exceeded the most optimistic projections. "Clinton Republicans expected to elect a part of their ticket Monday by close majorities," reported their editor, "but to get up Tuesday morning and learn that they had swept the board clean ... was fairly stunning." Republican candidates took all disputed positions except one: Ward 4's traditionally Democratic alderman's seat went to Irishman P. C. Donahue, but by only thirteen votes. Even the Republican alternative to Mayor Pollock, attorney C. W. Chase, narrowly captured Ward $4{ }^{47}$

"The Democracy was torn and divided," concluded the Republican Herald. "No part of its ticket was acceptable to all its voters; and so it was scratched or bolted entire on every hand." The Democratic Age agreed, correctly observing that "there are democrats enough in the city ... to elect a democratic ticket, . . . but they must vote the democratic ticket to do it." Hinting that a group of conspirators had purposely split the party, the Age's editor lamely urged reconciliation between the Irish and Germans: "Neither wing of the fighters is ahead. Both stand on equal ground. Both must forgive and forget and from this even ground go in hereafter to carry this city with the old time majorities. ${ }^{148}$ That reconciliation was not to be.

46. Clinton Weekly Age, 2, 9 March 1888; Stauffer, "Anti-Catholicism," part 2, 72; Clinton Daily Herald, 3 March 1888 (quotation). Clinton's Iowa Volks Zeitung, excerpted in the Clinton Daily Herald, 3 March 1888, is not extant prior to 1916. Alan Schroder, comp., A Bibliography of Iowa Newspapers, 1836-1976 (Iowa City, 1979), 71 .

47. Clinton Weekly Herald, 8 March 1888 (quotation); Clinton Weekly Age, 9 March 1888.

48. Clinton Weekly Herald, 8 March 1888; Clinton Weekly Age, 9 March 1888. Democratic strongholds in other cities came to share the experience of Clinton's Democracy. In traditionally Democratic Omaha, for example, APA support of the Republican Party enabled the Republicans to sweep the $1891 \mathrm{mu}-$ nicipal election by large majorities. Desmond, A.P.A., 64 . 
Within days of the city election, APA Council No. 1 moved to gain a seat on the local school board for one of its members. This was the first but not the last attempt by an APA chapter to counter alleged Catholic influence in public education through involvement in school board politics. ${ }^{4}$ "Usually school elections in Clinton are free from questions that tend to make them interesting," observed the Herald in 1888, "but not so this spring." Although there is no evidence of widespread dissatisfaction with the school board's policies, Clinton's APA seems to have mobilized over the board's connection with the financing for a new St. Mary's Catholic Church.

In 1884 Father E. J. McLaughlin had laid the cornerstone for the new edifice on a "beautiful and commanding site" acquired several years earlier. To raise money for the venture, McLaughlin offered to sell the currently occupied church and land to the town as the location for a planned high school. Late in 1886, the school board recommended an appropriation of funds to make the purchase, which voters then approved in a referendum accompanying the 1887 board election. ${ }^{51}$

The balloting, the press reported, had been "attended with more than ordinary interest [and] the number of votes cast was large." All funding questions, including the money earmarked to purchase the old St. Mary's, had passed easily. The election produced "no excitement over candidates or appropriations." Taxpayers' money, however, would substantially assist the raising of "a magnificent structure," the largest religious edifice in Clinton, whose Irish-Catholic parishioners constituted "one of the most powerful societies in the city. ${ }^{\prime \prime 2}$

49. For the APA and the politics of education in other locales, see Kinzer, Episode in Anti-Catholicism, 45, 83-84, 100-102. For the case of Worcester, Massachusetts, where, in the early 1890s, the local APA helped energize a campaign to unseat the school superintendent because his policies had been tailored to accommodate the desires of Irish Catholics, see Manfra and Kolesar, "Irishmen, Elites, and Reformers," 48-51.

50. Clinton Weekly Herald, 15 March 1888.

51. Clinton Weekly Age, 22 August 1884; Wolfe, History of Clinton County, 1:160, 161 (quotation), Clinton Morning News, 15 December 1886, 15 March 1887.

52. Clinton Morning News, 15 March 1887 (first quotation); Clinton Weekly Age, 11 March (second quotation), 21 October (third quotation) 1887; Youle, History, 37-38 (fourth quotation); Kinzer, Episode in Anti-Catholicism, 35. 
Against that background, a "citizens' caucus" met and nominated the APA's Jacob Walliker and one T. B. Rogers as candidates in the March 1888 school board election. "The ticket appeared to suit the majority," an editor observed, "but there was a minority report which was not heard until about noon Monday [that is, on election day itself], when a ticket appeared in the field headed by W. J. Young, Jr." The hastily drafted challenger was the eldest son of Clinton's most eminent lumber baron, a longtime foe of Arnold Walliker. Young's partisans also posted Rogers on their ticket, so that the only contest was between Walliker and Young. The APA founder won every voting unit but Irish Ward $4 .{ }^{53}$

Although the Republican Party clearly had benefited from the APA's machinations in the recent municipal election, Walliker's abrupt ascent to local office seemed to be cause for concern among the GOP elite. A week after the school board vote, Mayor Chase, apparently responding to the APA's growing political influence, thought it necessary to advise elected officials to "make no distinction on account of wealth or poverty, or on account of race, color, or religion." ${ }^{154}$

In 1889 , as a result of the introduction of two-year terms for all elected municipal officials, no mayoral contest enlivened Clinton's politics. Both parties, however, fielded slates for the spring election of aldermen; electors voted for one at-large representative and one alderman each from Wards 1 and 2. None of the nominees was Irish, partly because Ward 4 was not entitled to name a candidate that year. Election day proved to be "pretty quiet," with turnout down by approximately seven hundred voters from the preceding year. The results proved unsurprising. The Democrats won the at-large and Ward 1 contests, while the Republicans prevailed in Ward 2. Each party now held three seats on the city council, but only one seat was occupied by an Irishman-Ward 4's P. C. Donahue, a holdover from the election of $1887 .{ }^{55}$

53. Clinton Weekly Herald, 15 March 1888; Sieber, “Sawmilling on the Mississippi," 558.

54. Chase, quoted in Clinton Weekly Herald, 22 March 1888.

55. Clinton Morning News, 2, 5 (quotation) March 1889; Clinton Weekly Herald, 7 March 1889; Clinton Weekly Age, 8 March 1889. 
At that moment, Clinton's "several hundred" APA members could celebrate their political progress, but Council No. 1 would soon suffer internal conflict. ${ }^{56}$ In late 1887 Henry Bowers had turned his attention from the local business of Council No. 1 to make the APA a nationwide organization. He thus became a very busy rail traveler, organizing APA lodges not only within Iowa but at Detroit, Michigan; Janesville, Wisconsin; Bloomington, Freeport, Peoria, Rock Island, and Rockford, Illinois; and Omaha, Nebraska. ${ }^{57}$

Flushed with the success of his widespread organizing activities, Bowers impulsively decided that the time had come to sponsor the order's first national convention. He scheduled the meeting for December 18, 1889, at Belle Plaine, Iowa, a site probably selected for its location on a major rail line midway between important APA lodges in Omaha and Chicago. Bowers then appointed William Andrews, an APA founder and close personal friend, as Clinton's chapter delegate to the convention. ${ }^{58}$

Council No. 1's members divided over Bowers's action and expressed dismay that he had not left them enough time for a delegate selection by vote. On January 12, 1890, Council No. 1 therefore resolved to oppose Bowers's appointment of Andrews and to condemn Bowers for failing to offer them sufficient notice of the national meeting. They then signed the resolution and sent it to the National Council. According to Ruth Stough, "when they saw their [local] council . . . pulling away from the purposes for which it was originally founded, many of the members dropped [out of] the organization, among them some of the founders." Since Arnold Walliker was Stough's informant, one assumes that he, too, defected. ${ }^{59}$

Following the evident break with Bowers, Clinton's APA did not end its involvement in local politics, but it did change

56. Arnold Walliker estimated the membership in his interview with Ruth Stough. Stough, "American Protective Association," 86.

57. Kinzer, Episode in Anti-Catholicism, 54-55.

58. Ibid., 55; Stough, "American Protective Association," 86-87.

59. For Arnold Walliker's recollections, see Stough, "American Protective Association," 86-87. Neither the chapter's response to the Belle Plaine meeting nor the meeting itself is mentioned in any Clinton County newspaper. Belle Plaine's newspaper is not extant for 1889. 
strategy. Instead of working through the Republican Party, as before, it chose to field its own ticket for the March 1890 city election. This third-party tactic was reminiscent of the Knights' successful campaign in 1886 and of Walliker's unsuccessful independent run the following year. ${ }^{60}$

Toward the end of February 1890, a petition circulating in downtown Clinton urged "all patriotic residents of our beautiful city to meet in mass convention" to devise an independent slate "selected from among our citizens of known probity and business capacity." During the town's recent political turbulence, the petition continued, the public welfare had been subordinated to "success of party." This had allowed the emergence of "a direful brood of professional office seekers: men without honor, men without integrity, men without ability, drones as it were for the public hive, adventurers seeking plunder off the industries of the people." ${ }^{\prime 61}$

A weekend issue of the News carried the petition and a partial list of its 393 signatories, among them "a large number of prominent businessmen." Within hours, word had leaked that the document targeted the city's political elite and its Irish allies. "If there ever were angry men in town it was Saturday when the business men who were singled out of those who signed the lists purporting to call a citizens' convention saw their names in the NEWS," its apologetic editor reported. Those men "want it distinctly under[stood]," he added, "that when they signed the petition they believed it to be non-political, non-sectarian, and only and purely for the purpose of putting up a ticket entirely, regardless of political or other faith, with the commercial betterment of Clinton solely in view." They now wished "to let all their friends know that they are yet their friends. ${ }^{162}$ Clinton's business community clearly did not relish losing Irish commercial patronage. Given the city's recent political history, it seems likely that the larger alarm had to do with the town's traditional leadership once again losing authority over public

60. APA chapters in Chicago and elsewhere would later turn to the third-party strategy. Jensen, Winning of the Midwest, 223; Desmond, A.P.A., 72.

61. Petition quoted in Clinton Morning News, 22 February 1890.

62. Clinton Morning News, 22, 23 February 1890. 
policy to a group of off-center political reformers, whatever their stripe.

The following Tuesday, February 25, the announced Citizens' caucus convened at the Davis Opera House at 7:30 p.m. An estimated three hundred people participated, with another hundred as onlookers. APA members apparently showed up in force; those assembled selected Arnold Walliker as chair. They then unanimously chose F. A. Seavey, an old-stock Democrat with a political grudge against the Irish, to head their ticket. Significantly, the selection for the second most important office at stake, that of police judge, went to APA charter member Simon Woldenberg. The caucus also chose an APA founder, Jacob Walliker, to sit on a four-member central committee. For several other offices, the caucus nominated Scandinavians and Germans, among them Jens Hansen, president of the city's Danish Benevolent Society, and Louis Seeber, vice-president of the Clinton Turn and Benevolent Verein Voraerts. ${ }^{63}$

Clearly, the APA was the moving force behind the political gathering, and evidently most of those attending were ex-Mayor Walliker's loyal supporters-German and Scandinavian workingmen. "With barely one or two exceptions," noted an editor, "not a single business man in the city participated." The same editor cautioned the exceptions to "shake off all connection with it as they would a viper that caresseth in the daytime but stingeth in the night." Louis Seeber, the Citizens' German nominee for alderman-at-large and owner of a downtown barbershop, heeded that advice. He published a notice in the News, removing his name from the ticket and declaring himself "in no degree in sympathy with the movement. ${ }^{\prime \prime 4}$

63. Clinton Morning News, 26 February 1890; Clinton Weekly Herald, 27 February 1890. For Seavey, see Tenth Census, Clinton County, district 289, dwelling 568. In 1882 Seavey had narrowly won reelection as Clinton's mayor. The Democrats in convention had nominated him for a second term over the objections of Ward 4's Irish delegates, who wanted one of their own to head the ticket. The Irish responded by running their man against Seavey as an independent. Clinton Weekly Age, 3, 10 March 1882. For Jens Hansen, a district assessor nominee, and Louis Seeber, see Directory for 1885-86, 31, 134.

64. Clinton Morning News, 27 February (first quotation), 2 March (second quotation) 1890. 
The slate's critics seemed convinced that whatever else it represented, the Citizens' ticket was an expression of support for ex-mayor Walliker's old reform agenda. As the editor of the News put it,

Clinton nipped Anarchism in the bud three years ago, but it would seem that the roots are still pregnant with life... Any movement that has for its underlying purpose the inciting of social disorder should receive no recognition whatever, but should be stamped out of existence. The NEWS does not say that Tuesday night's meeting was of this sort but it is easy to see where it would soon drift to if put in the hands of the man who represented the gathering as chairman.

The next day, February 28, another editor added that "the ticket was gotten up especially to beat one or two democrats who will likely be nominated [at the Democratic convention] to-night. ${ }^{\prime 65}$

That evening the Democrats clearly communicated that they were back in force, confident of ending the Republicans' twoyear control of city hall. "The prospects of a wild and stormy time ... drew out a large crowd," reported the Herald's man on the scene, "and the hall was filled with a motley and expectant throng, and vile tobacco smoke." At one point, "so enthusiastic was the discussion [that] nothing less than a meat-ax could have restored quiet for some time." In the end, the Democrats selected a slate that included three Irishmen. When someone proposed that the Citizens' nominee for superintendent of markets (who happened to be a Ward 2 Democrat) also be made the Democratic candidate for that position, "a big kick was raised." Martin Hassett, who had presided over the withdrawal of Knights of Labor support for Arnold Walliker in 1887, "arose to his feet and said he didn't believe this convention wanted anything to do with a man who had been nominated by the Walliker convention." After that, not even the delegate who had proposed the man's candidacy dared to vote for him. ${ }^{66}$

65. Clinton Morning News, 27 February 1890 (first quotation); Clinton Weekly Age, 28 February 1890 (second quotation).

66. Clinton Weekly Herald, 3 (first quotation), 6 (second quotation) March 1890; Clinton Morning News, 1 March 1890 (third quotation). The main excitement was prompted by the contest between two Irishmen for the marshal's nomi- 
On election day, March 3, 1890, the Democrats triumphed. Two of the three Irish candidates won office, the third losing his bid for city marshal to the Citizens'-endorsed Republican incumbent. No other Citizens' nominees won. Support for Woldenberg, an APA member, is of particular interest. Even in Ward 1, where he did the best, he earned only 23 percent of the ballots. "What the so-called citizens' movement accomplished is not distinctly visible to the naked eye," wrote the Republican editor of the Herald. "Possibly it assisted in the election of the Republican nominee for Marshal, but it is to be apprehended that it was more potent in causing the defeat for reelection of [other] deserving Republican officials. ... It was an ill-advised movement from the start, and signally failed to accomplish anything that it was supposed to be aiming at." ${ }^{167}$

Indeed, not only had the APA's gambit guaranteed Democratic victory in most races by splitting the Republican vote, it apparently also moved the GOP elite once again to back a Democrat-in this instance, T. M. Gobble - to head Clinton's government. As the Herald reported, Gobble "had a clear majority over both the Republican and 'citizens' candidates," and he enjoyed the "confidence of the business interests, ... which are largely Republican." Like his Democratic predecessors, Mayor Gobble could be counted on to promote the business community's fundamental policy concerns. ${ }^{68}$

Nine days after its stunning municipal defeat, the dispirited APA also lost its seat on the school board. Jacob Walliker did not run for reelection in the 1890 school election, and the writein candidacy of Henry Bowers garnered a mere three votes. ${ }^{69}$

The results of the 1890 municipal and school elections marked the demise of the city's APA, but more importantly, they ended

nation, a fight that had begun in the ward caucuses the previous evening. Clinton Morning News, 28 February 1890; Clinton Weekly Age, 28 February 1890; Clinton Weekly Herald, 6 March 1890 . For the unexciting Republican caucuses and convention, see the Clinton Weekly Age, 28 February 1890.

67. Clinton Weekly Herald, 6 March 1890 . The voting returns as printed in the Clinton Weekly Age, 7 March 1890, are partly illegible; see instead those carried by the Clinton Weekly Herald, 6 March 1890.

68. Clinton Weekly Herald, 6 March 1890.

69. Ibid., 13 March 1890. 
the challenge to entrepreneurial hegemony that had begun in 1885 with the advent of the Knights of Labor. "The wiping out of this third party movement was so effectual," proclaimed a local editor, "that the managers would now feel like hiding their diminished heads. There is no room in Clinton for any party that chooses for its leader the man [Arnold Walliker] whom the citizens of this city have twice sat down upon, the last time on Monday of this week. The lesson," he concluded, "ought to be a salutary one." ${ }^{170}$

THREE YEARS LATER, in 1893, Henry Bowers lost personal control of the APA to a vastly expanded national membership that replaced him with Michigan's William Traynor as supreme president. When Bowers regained its leadership in 1898, the organization was only a shadow of its former self, and what remained of the APA died with its founder in $1911 .^{71}$ By that date, most Clintonians had probably forgotten the circumstances of the APA's hometown rise and fall back in the late eighties and early nineties.

In retrospect, the egalitarian, prolabor, and antimonopoly origins and early career of the APA are clearly discernable. Local Irish Democrats made up the voter rank and file that had destroyed Clinton's Knights of Labor regime and returned political control of the town to its economic elite. The anti-Irish crusade, then, was essentially a continued revolt - in different form-against municipal policies that supported the business community's version of civic progress.

Whether or not similar local contexts yielded similar political behaviors elsewhere awaits further study. To date, historians have only dimly glimpsed APA themes beyond a narrow antiCatholicism. Melvin Holli, for instance, notes in passing that Detroit's flourishing APA chapter attacked "corporate capitalism" as well as Catholicism. Similarly, Gerald Marsden's study of one of the APA's regional newspapers, the Wisconsin Patriot, reveals that it vigorously supported workers and small businessmen. "Allow no special privileges ... to any corporation, sect,

70. Clinton Morning News, 5 March 1890.

71. Kinzer, Episode in Anti-Catholicism, 90-93, 236-39. 
creed or class," exhorted its editor. And, observes John Higham, "one A.P.A. council (championing small business against monopolies) resolved that no one should be allowed to accumulate more than a million dollars." 72

On the national level, in Higham's words, the APA "reverberated with vague alarms at plutocracy," although such concerns, he adds, "formed no part of its official creed." Far from dealing directly with social and economic conflicts, the APA diverted them into religious and nationalistic channels. "The association," he says, "deliberately excluded the major issues of the day when it drew up a formal program in 1894." ${ }^{\prime 73}$

Probably nothing has misled scholars more than Henry Bowers's own rewrite of APA history, which accompanied his metamorphosis from left-of-center Clinton politician into national spokesman for America's patriotic right. When much later describing the society's creation, Bowers offered a description that had little to do with the actual circumstances of its birth. Instead, he transformed the founders' immediate anxiety about local public policy into a universal religious menace. "The condition of affairs in this country in 1887," he said, "was such that the institutions of our Government were controlled and the patronage was doled out by an ecclesiastical element under the direction and heavy hand of a foreign ecclesiastical potentate. ... Seeing these things, I felt that it was necessary that something should be done. ${ }^{\prime 74}$ The worldwide machinations of the Pope, not the grip of a conservative political coalition in a provincial Iowa river town, had become justification for the critical meeting of March 13, 1887.

72. Melvin Holli, Reform in Detroit: Hazen S. Pingree and Urban Politics (New York, 1969), 65; Marsden, "Patriotic Societies," 289; Higham, Strangers in the Land, 82.

73. Higham, Strangers in the Land, 82-83.

74. Quoted in Stevens, Cyclopedia of Fraternities, 295. Bowers made this revisionist statement in an interview with the Mechanicsville, Iowa, American Advocate. According to Kinzer, the Advocate, published from 1898 to 1900, was the last organ to espouse the APA line. Its extant issues are housed in the library of the University of Washington, Seattle. Kinzer, Episode in Anti-Catholicism, 234, $272 n, 327$. 
The newly published edition of a popular college history textbook includes a capsule summary of the APA's origins: "In 1887, Henry Bowers, a self-educated lawyer obsessed with a hatred of Catholics and foreigners, founded the American Protective Association, a group committed to stopping immigration. ${ }^{175}$ Whether or not that synopsis accurately distills the current historical literature is arguable; that it inadequately summarizes the origins of the APA is beyond dispute. Surely the men who gathered in Bowers's law office that memorable Sunday deserve a more nuanced and a far more interesting epitaph.

75. Alan Brinkley, The Unfinished Nation: A Concise History of the American People, 2d ed. (New York, 1997), 515. 
Copyright of Annals of Iowa is the property of State of Iowa, by \& through the State Historical Society of Iowa and its content may not be copied or emailed to multiple sites or posted to a listserv without the copyright holder's express written permission. However, users may print, download, or email articles for individual use. 